\title{
Erythrophagocytosis by Neutrophils in Paroxysmal Cold Hemoglobinuria
}

Sampagar $A^{1}$, Bartakke $S^{2 *}$, Lukade $U^{3}$ and Sethuratnam $\mathbf{S}^{3}$

${ }^{1}$ Department of Pediatrics, J awaharlal Nehru Medical College and Hospital, India

${ }^{2}$ Department of Clinical Hematology, Aditya Birla

Memorial Hospital, India

${ }^{3}$ Department of Pathology, Aditya Birla Memorial Hospital, India

*Correspondling author: Sandip Bartakke, Department of Clinical Hematology, Aditya Birla Memorial Hospital, Pune, India

Received: April 12, 2017; Accepted: April 27, 2017; Published: May 17, 2017

\section{Clinical Image}

Paroxysmal Cold Hemoglobinuria $(\mathrm{PCH})$ is the most common cause of acute autoimmune hemolytic anaemia in children $[1,2]$. The presence of marked erythrophagocytosis by neutrophils is a relatively rare observation on blood smears, but it is a prominent feature of $\mathrm{PCH}$ [3-5]. This case highlights the necessity for clinicians to be aware of the importance of erythrophagocytosis in diagnosis of $\mathrm{PCH}$.

A 4-year-old boy presented with 4 days history of fever, jaundice and dark colored urine. On examination, he had pallor and icterus. A complete blood count was remarkable for haemoglobin of $41 \mathrm{gm} / \mathrm{l}$, a white cell count of $27.1 \times 10^{9} / 1$ and a platelet count of $367 \times 10^{9} / 1$. The reticulocyte count was $2 \%$. Serum lactate dehydrogenase was significantly elevated at $4700 \mathrm{U} / \mathrm{L}$. His serum creatinine was $2.0 \mathrm{mg} /$ $\mathrm{dl}$ and urine analysis showed presence of hemoglobin.

The peripheral blood smear showed occasional spherocytes and neutrophilic leucocytosis. Approximately $22 \%$ of neutrophils showed

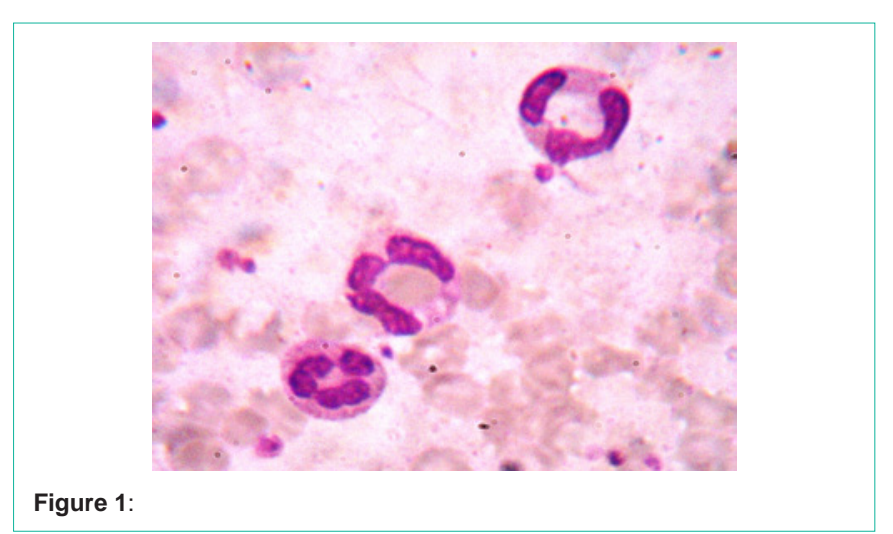

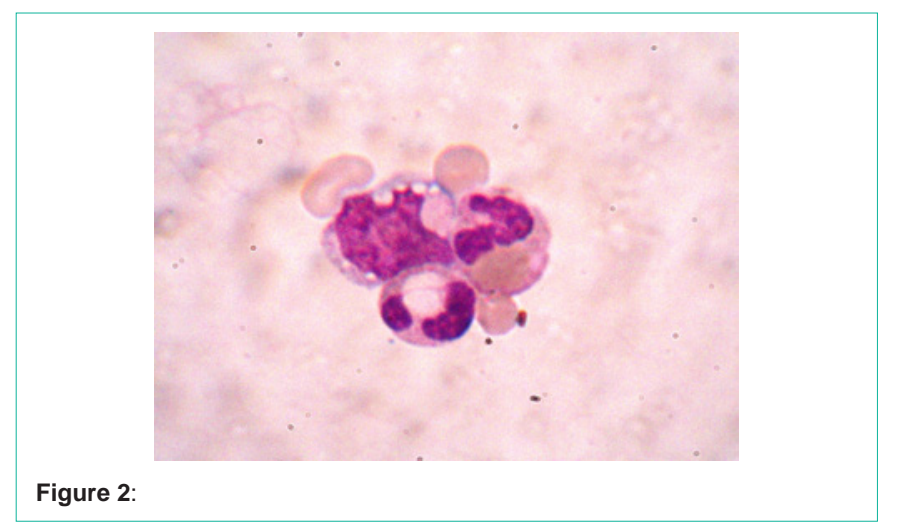

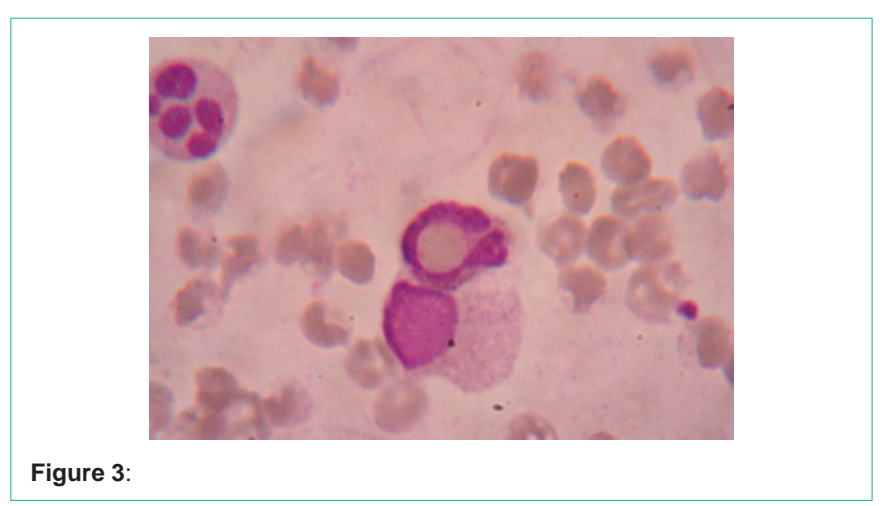

erythrophagocytosis. The direct antiglobulin test was strongly positive with complement and was negative with polyspecific antihuman globulin. The above laboratory results were suggestive of intravascular haemolysis due to cold-reactive autoantibody. The diagnosis of $\mathrm{PCH}$ was confirmed by positive Donath- Landsteiner antibody test.

\section{References}

1. Weerakkody RM, Ranasinghe NN, Sivagnanam FG. A case of paroxysmal cold haemoglobinuria following chickenpox. Ceylon Med J. 2010; 55: 96.

2. Mukhopadhyay S, Keating L, Souid AK. Erythrophagocytosis in paroxysmal cold hemoglobinuria. Am J Hematol. 2003; 74: 196-197.

3. Chandrashekar V, Soni M. Florid Erythrophagocytosis on the Peripheral Smear. J Lab Physicians. 2012; 4: 59-61.

4. Heddle NM. Acute paroxysmal cold hemoglobinuria. Transfus Med Rev. 1989; 3: 219-229.

5. Garratty G. Erythrophagocytosis on the peripheral blood smear and paroxysmal cold hemoglobinuria. Transfusion. 2001; 41: 1073-1074.
Ann Hematol Oncol - Volume 4 Issue 5 - 2017 ISSN : 2375-7965 | www.austinpublishing group.com Bartakke et al. (C) All rights are reserved
Citation: Sampagar A, Bartakke S, Lukade $U$ and Sethuratnam S. Erythrophagocytosis by Neutrophils in Paroxysmal Cold Hemoglobinuria. Ann Hematol Oncol. 2017; 4(5): 1151. 